TAP CHÍ KHOA HOC ĐẠI HỌC TÂN TRÀO
ISSN: 2354 - 1431

\title{
THỤC TRẠNG NGHÈO ĐÓI TẠI XÃ THƯỢNG NUNG HUYỆN VÕ NHAI, TỈNH THÁI NGUYÊN
}

\author{
Trần Thị Hồng ${ }^{1 *}$ \\ ${ }^{I}$ Truò̀ng Đại học Khoa học-Đại học Thái Nguyên \\ *Email: hongtt@tnus.edu.vn
}

Thông tin bài viết

Ngày nhận bài:

27/7/2020

Ngày duyệt đăng:

20/9/2020

\section{Tóm tắt}

Bài viết tập trung làm rõ thực trạng nghèo đói cũng như phân tích những nguyên nhân dẫn đến nghèo đói và việc thực hiện các chính sách xóa đói giảm nghèo của xã Thượng Nung, huyện Võ nhai, tỉnh Thái Nguyên trong giai đoạn 2016-2019. Từ đó, đề xuất một số giải pháp góp phần giảm nghèo đói trên địa bàn xã trong thời gian tới.

Từ khóa:

Nghèo đói, xóa đói, giảm

nghèo, công tác xóa đói, chính

sách xóa đói giảm nghèo.

\section{1. Đặt vấn đề nghiên cứu}

Ngày nay, nghèo đói đang trở thành một vấn đề cấp bách của nhiều quốc gia trên thế giới, đặc biệt là ở các nước chậm phát triển và đang phát triển. Mỗi quốc gia muốn thực hiện được mục tiêu phát triển kinh tế - xã hội bền vững thì không thể không giải quyết vấn đề nghèo đói. Trong những năm qua, Việt Nam đã đạt được nhiều thành tựu to lớn về xóa đói giảm nghèo, được các tổ chức quốc tế và các nước đánh giá cao về sự quyết tâm chống nghèo đói của Chính Phủ Việt Nam.

Võ Nhai là một huyện miền núi có diện tích tự nhiên lớn nhất trong số 9 huyện và thành phố của tỉnh Thái Nguyên. Trong thời gian qua, mặc dù đạt được nhiều kết quả đáng ghi nhận trong công tác giảm nghèo, là địa phương có tỷ lệ giảm nghèo nhanh của tỉnh Thái Nguyên. Riêng năm 2017, tỷ lệ giảm nghèo của Võ Nhai đạt trên $6 \%$, đứng thứ 2 toàn tỉnh, song vẫn là địa phương có tỷ lệ hộ nghèo cao nhất tỉnh.

Thượng Nung là một trong xã vùng cao đặc biệt khó khăn của huyện Võ Nhai. Năm 2019, toàn xã có
7 xóm, quy mô 4229 ha và 525 hộ với 2131 nhân khẩu, $100 \%$ là đồng bào dân tộc thiểu số (Tày và Mông), đời sống chủ yếu dựa vào làm nương rẫy, trình độ dân trí còn thấp. Số hộ nghèo tính đến tháng 12 năm 2019 vẫn là 203 hộ chiếm 38,66 \%. Số hộ cận nghèo là 87 hộ, chiếm 16.5\% . (Theo báo cáo của UBND xã Thượng Nung năm 2019). Vậy, nguyên nhân nào dẫn đến thực trạng nghèo đói và cần có những giải pháp nào để giảm nghèo đói tại xã Thượng Nung trong thời gian tới? Xuất phát từ lí do trên, tác giả đã lựa chọn vấn đề "Thực trạng nghèo đói tại xã Thuợng Nung, huyện Võ Nhai, tỉnh Thái Nguyên", đề nghiên cứu. Ở phạm vi bài viết này, tác giả phân tích một số nguyên nhân cơ bản dẫn đến nghèo đói và đề xuất một số giải pháp góp phần giảm nghèo đói trên địa bàn xã trong thời gian tới.

\section{Nội dung và phương pháp nghiên cứu}

\subsection{Nội dung nghiên cúu}

Bài viết tập trung nghiên cứu 2 nội dung chính:

- Phân tích thực trạng nghèo đói cũng như các nguyên nhân dẫn đến nghèo đói và làm rõ việc thực hiện các chính sách xóa đói giảm nghèo của xã 
Thượng Nung, huyện Võ Nhai, tỉnh Thái Nguyên trong giai đoạn 2016-2019.

- Đề xuất một số giải pháp góp phần giảm nghèo đói trên địa bàn xã trong thời gian tới tại xã Thượng Nung, huyện Võ Nhai, tỉnh Thái Nguyên trong thời gian tới.

\subsection{Phưong pháp nghiên cúu}

Để thực hiện bài viết này, tác giả đã sử dụng một số phương pháp nghiên cứu sau:

- Phương pháp phân tích và tổng hợp;

- Phương pháp phỏng vấn sâu: Tiêu chí chọn mẫu phỏng vấn sâu.

Một là: Với đối tượng là cán bộ xã: Tác giả tiến hành phỏng vấn 01 chủ tịch Ủy ban nhân dân xã Thượng Nung; 01 công chức chuyên trách mảng công tác xóa đói giảm nghèo của xã và 07 trưởng xóm người được Ủy ban nhân xã Thượng Nung giao nhiệm vụ quản lý các hộ dân trong phạm vi được giao để hiểu rõ hơn về tình hình các hộ dân của xóm nhất là các hộ dân thuộc diện nghèo và cận nghèo.

Hai là: Với đối tượng là người dân: Tác giả lựa chọn dựa vào tiêu chí là các hộ dân thuộc diện nghèo và cận nghèo do Ủy ban nhân xã cung cấp trên cơ sở lấy mẫu ngẫu nhiên.

- Ngoài ra, tác giả còn sử dụng cả phương pháp quan sát trong quá trình nghiên cứu.

\section{Kết quả nghiên cứu}

\subsection{Khái niệm nghèo đói}

Hội nghị bàn về giảm nghèo đói ở khu vực Châu Á - Thái Bình Dương do ESCAP tổ chức tại Băng Cốc tháng 9/1993 đã đưa ra khái niệm và định nghĩa về nghèo đói như sau: "Nghèo đói là tình trạng một bộ phận dân cu không được huởng và thỏa mãn nhũ̃ng nhu cầu co bản của con ngườ đã được xã họi thù̀a nhận thùy theo trình độ phát triển kinh tế- xã hội và phong tục tập quán của các địa phuoong”. Có thể xem đây là định nghĩa chung nhất về nghèo đói, trong đó các tiêu chí và chuẩn mực đánh giá về nghèo đói còn để ngỏ về mặt lượng hóa, bởi nó chưa tính đến những khác biệt và độ chênh lệch giữa các vùng, các điều kiện lịch sử cụ thể quy định trình độ phát triển ở mỗi nơi. Ở Việt Nam thì tách riêng "đói" và "nghèo" thành 2 khái niệm riêng biệt.

- Nghèo: là tình trạng một bộ phận dân cư chỉ có điều kiện thoả mãn một phần những nhu cầu tối thiểu cơ bản của cuộc sống và có mức sống thấp hơn mức sống trung bình của cộng đồng xét trên mọi phương diện.

- Đói: là tình trạng một bộ phận dân cư nghèo có mức sống dưới mức tối thiểu và thu nhập không đủ đảm bảo nhu cầu và vật chất để duy trì cuộc sống. Đó là các hộ dân cư hàng năm thiếu ăn, đứt bữa từ 1 đến 3 tháng, thường vay mượn cộng đồng và thiếu khả năng chi trả. Giá trị đồ dùng trong nhà không đáng kể, nhà ở dốt nát, con thất học, bình quân thu nhập dưới $13 \mathrm{~kg}$ gạo/người/tháng (tương đương 45.000VND).

Qua các định nghĩa trên, ta có thể đưa ra định nghĩa chung về nghèo đói: "là tình trạng một bộ phận dân cu không có nhũng điều kiện về cuộc sống $n h u$ ăn, mặc, ở, vệ sinh, y tế, giáo duc, đi lại, quyền được tham gia vào các quyết định của cộng đồng".

\subsection{Thục trạng nghèo đói tại xã Thựng Nung,} huyện Võ Nhai giai đọ̣n 2016-2019

Xã Thượng Nung là một xã đặc biệt khó khăn của huyện Võ Nhai, trong những năm qua Xã đã đạt được một số kết quả nhất định về công tác xóa đói giảm nghèo như: Hộ nghèo từ 276 hộ năm 2016 xuống còn 203 hộ năm 2019 (giảm 15,67\%). Số hộ cận nghèo từ 53 hộ năm 2016 tăng lên 87 hộ năm 2019 (Tăng 5,9\%) (Nguồn: Theo báo cáo của Ủy ban nhân dân xã Thuợng Nung). Sở dĩ, có được kết quả kể trên là do hàng năm Ủy ban nhân dân xã đã kịp thời phân công cụ thể từng thành viên phụ trách chỉ đạo theo dõi thực hiện mục tiêu giảm nghèo trên địa bàn xã; gắn Chương trình giảm nghèo với các chương trình phát triển kinh tế - xã hội trọng tâm, trọng điểm; coi đó là một trong những chương trình ưu tiên hàng đầu trong quá trình phát triển kinh tế - xã hội của địa phương nên đã mang lại hiệu quả cao cho mục tiêu giảm nghèo hàng năm của xã được thể hiện ở Bảng 1 dưới đây.

Bảng 1: Thục trạng số hộ nghèo, cận nghèo trên địa bàn xã Thuợng Nung giai đoạn 2016 - 2019

\begin{tabular}{|c|c|c|c|c|c|}
\hline \multirow{2}{*}{ Năm } & \multirow{2}{*}{$\begin{array}{c}\text { Tổng } \\
\text { số hộ dân cư }\end{array}$} & \multicolumn{2}{|c|}{$\begin{array}{c}\text { Số } \\
\text { Hộ nghèo }\end{array}$} & \multicolumn{2}{|c|}{$\begin{array}{c}\text { Số hộ } \\
\text { Cận nghèo }\end{array}$} \\
\cline { 3 - 6 } & & $\begin{array}{c}\text { Số } \\
\text { lượng }\end{array}$ & $\begin{array}{c}\text { Tỷ lệ } \\
(\%)\end{array}$ & $\begin{array}{c}\text { Số } \\
\text { lượng }\end{array}$ & $\begin{array}{c}\text { Tỷ lệ } \\
(\%)\end{array}$ \\
\hline 2016 & 508 & 276 & 54,33 & 53 & 10,4 \\
\hline 2017 & 514 & 253 & 49,22 & 69 & 13,4 \\
\hline 2018 & 515 & 230 & 44,66 & 78 & 15,1 \\
\hline 2019 & 525 & 203 & 38,66 & 87 & 16,5 \\
\hline
\end{tabular}

(Nguồn: Báo cáo của Xã Thuợng Nung, huyện Võ Nhai, tỉnh Thái Nguyên tháng 12/2019) 
Số hộ nghèo và cận nghèo phân theo đối tượng cũng có xu hướng giảm hàng năm. Cụ thể: Hộ nghèo và cận nghèo thuộc diện người có công năm 2016 là 6 hộ thì đến năm 2019 thì xuống còn 4 hộ. Số hộ nghèo và cận nghèo thuộc đối tượng bảo trợ xã hội năm 2016 là 23 hộ, giảm xuống còn 16 hộ năm 2019 được thể hiện ở Bảng 2 dưới đây.

Bảng 2: Số hộ nghèo phân theo đối tuợng giai đoạn 2016-2019

tại xã Thuợng Nung huyện Võ Nhai, tỉnh Thái Nguyên

\begin{tabular}{|l|c|c|c|}
\hline \multirow{2}{*}{ Năm } & \multicolumn{2}{|c|}{ Hộ nghèo thuộc các nhóm đối tượng } & \multirow{2}{*}{ Tổng } \\
\cline { 2 - 4 } & $\begin{array}{c}\text { Hộ nghèo có thành viên thuộc đối } \\
\text { tuộng chính sách nguoòi có công }\end{array}$ & $\begin{array}{c}\text { Hộ nghèo có thành viên thuộc đối } \\
\text { tuoọng bảo trọ́ xã hội }\end{array}$ & \\
\hline 2016 & 6 & 23 & 29 \\
\hline 2017 & 6 & 23 & 29 \\
\hline 2018 & 4 & 17 & 19 \\
\hline 2019 & 3 & 16 & 21 \\
\hline
\end{tabular}

(Nguồn: Báo cáo của Xã Thuợng Nung, huyện Võ Nhai, tỉnh Thái Nguyên)

Theo kết quả thống kê thì $7 / 7$ xóm của xã Thượng Nung đều là có hộ nghèo và cận nghèo. Tỉ lệ hộ nghèo tại các xóm của xã thường giao động từ $15 \%$ đến $93 \%$ có xu hướng giảm, thậm chí là giảm mạnh qua các năm trong giai đoạn 20162019. Chẳng hạn: xóm Lũng Luông, năm 2016 có tỉ lệ hộ nghèo chiếm 93,3\%, (114/116 hộ) những đến năm 2019 giảm xuống còn 79,3\% (92/116 hộ). Tiếp đến là xóm Lũng Hoài với 40/43 hộ nghèo năm 2016, chiếm $93 \%$, có xu hướng tăng thêm 02 hộ vào năm 2018 nhưng năm 2019 chỉ còn 36/45 hộ, chiếm 80,0\%. Xóm có tỉ lệ hộ nghèo thấp nhất là xóm An Thành năm 2016 với 12/79 hộ, chiếm
15\% nhưng đến tháng 12/2019 xóm giảm xuống còn 8 hộ, chiếm 9,6\%.

Tỉ lệ hộ cận nghèo tại 7/7 xóm của xã Thượng Nung có xu hướng tăng nhẹ qua các năm trong giai đoạn 2016-2019. Trong đó, xóm có tỉ lệ hộ cận nghèo cao nhất là xóm Lục Thành với 18 hộ cận nghèo năm 2016, chiếm 29,03\% đến năm 2019 tăng lên 21 hộ, chiếm $32,2 \%$. Tiếp đến là Xóm Lũng Cà từ $4 / 34$ hộ, năm 2016, chiếm $11,7 \%$ tăng lên 12 hộ, chiếm 28,6\% năm 2019. Xóm Trung Thành từ 7/105 hộ, năm 2016, chiếm 6,7\% tăng lên 18 hộ, chiếm 16,4\% năm 2019, điều đó được thể hiện ở Bảng 3 dưới đây.

Bảng 3: Thưc trạng số hộ nghèo, cần nghèo tại 7 గ xóm thuộc xã Thuợng Nung giai đoạn 2016-2019

\begin{tabular}{|c|c|c|c|c|c|c|c|}
\hline \multirow[t]{2}{*}{ Năm } & \multirow[t]{2}{*}{ Xóm thuộc xã } & \multirow[t]{2}{*}{$\begin{array}{c}\text { Tổng số hộ } \\
\text { dân cư }\end{array}$} & \multirow[t]{2}{*}{$\begin{array}{c}\text { Số hộ dân tộc } \\
\text { thiểu số }\end{array}$} & \multicolumn{2}{|c|}{$\begin{array}{l}\text { Tổng số } \\
\text { hộ nghèo }\end{array}$} & \multicolumn{2}{|c|}{$\begin{array}{c}\text { Tổng số } \\
\text { hộ cận nghèo }\end{array}$} \\
\hline & & & & Số luộng & Tỉlẹ & Số lự̆ng & Tỉlệ \\
\hline \multirow{7}{*}{2016} & An Thành & 79 & 79 & 12 & 15,2 & 10 & 12,7 \\
\hline & Trung Thành & 105 & 105 & 39 & 37,1 & 7 & 6,7 \\
\hline & Lục Thành & 62 & 62 & 17 & 27,4 & 18 & 29,0 \\
\hline & Tân Thành & 63 & 63 & 26 & 41,3 & 7 & 11,1 \\
\hline & Lũng Cà & 34 & 34 & 28 & 82,4 & 4 & 11,8 \\
\hline & Lũng Hoài & 43 & 43 & 40 & 93,0 & 3 & 7,0 \\
\hline & Lũng Luông & 122 & 122 & 114 & 93,4 & 4 & 3,3 \\
\hline \multicolumn{2}{|r|}{ Tổng } & 508 & 508 & 276 & 54,33 & 53 & 10,4 \\
\hline \multirow[b]{5}{*}{2017} & An Thành & 80 & 80 & 12 & 15,0 & 8 & 10,0 \\
\hline & Trung Thành & 108 & 108 & 33 & 30,6 & 12 & 11,1 \\
\hline & Luc Thành & 61 & 61 & 13 & 21,3 & 18 & 29,5 \\
\hline & Tân Thành & 63 & 63 & 22 & 34,9 & 12 & 19,0 \\
\hline & Lũng Cà & 35 & 35 & 24 & 68,6 & 11 & 31,4 \\
\hline
\end{tabular}




\begin{tabular}{|c|c|c|c|c|c|c|c|}
\hline \multirow[t]{4}{*}{ Năm } & \multirow[t]{2}{*}{ Xóm thuộc xã } & \multirow[t]{2}{*}{$\begin{array}{c}\text { Tổng số hộ } \\
\text { dân cư }\end{array}$} & \multirow[t]{2}{*}{$\begin{array}{c}\text { Số hộ dân tộc } \\
\text { thiểu số }\end{array}$} & \multicolumn{2}{|c|}{$\begin{array}{l}\text { Tổng số } \\
\text { hộ nghèo }\end{array}$} & \multicolumn{2}{|c|}{$\begin{array}{c}\text { Tổng số } \\
\text { hộ cận nghèo }\end{array}$} \\
\hline & & & & Số lự̂ng & Tillệ & Số lự̆ng & Tỉlẹ \\
\hline & Lũng Hoài & 43 & 43 & 40 & 93,0 & 2 & 4,7 \\
\hline & Lũng Luông & 124 & 124 & 109 & 87,9 & 6 & 4,8 \\
\hline & Tổng & 514 & 514 & 253 & 49,22 & 69 & 13,4 \\
\hline \multirow{7}{*}{2018} & An Thành & 81 & 81 & 8 & 9,9 & 5 & 6,2 \\
\hline & Trung Thành & 108 & 108 & 30 & 27,8 & 16 & 14,8 \\
\hline & Lục Thành & 63 & 63 & 10 & 15,9 & 19 & 30,2 \\
\hline & Tân Thành & 62 & 62 & 14 & 22,6 & 18 & 29,0 \\
\hline & Lũng Cà & 42 & 42 & 27 & 64,3 & 13 & 31,0 \\
\hline & Lũng Hoài & 43 & 43 & 42 & 97,7 & 1 & 2,3 \\
\hline & Lũng Luông & 116 & 116 & 99 & 85,3 & 6 & 5,2 \\
\hline \multicolumn{2}{|r|}{ Tổng } & 515 & 515 & 230 & 44,66 & 78 & 15,1 \\
\hline \multirow{7}{*}{2019} & An Thành & 83 & 83 & 8 & 9,6 & 5 & 6,0 \\
\hline & Trung Thành & 110 & 110 & 26 & 23,6 & 18 & 16,4 \\
\hline & Lục Thành & 65 & 65 & 7 & 10,8 & 21 & 32,3 \\
\hline & Tân Thành & 64 & 64 & 9 & 14,1 & 18 & 28,1 \\
\hline & Lũng Cà & 42 & 42 & 25 & 59,5 & 12 & 28,6 \\
\hline & Lũng Hoài & 45 & 45 & 36 & 80,0 & 5 & 11,1 \\
\hline & Lũng Luông & 116 & 116 & 92 & 79,3 & 8 & 6,9 \\
\hline \multicolumn{2}{|r|}{ Tổng } & 525 & 525 & 203 & 38,66 & 87 & 16,5 \\
\hline
\end{tabular}

(Nguồn: Báo cáo của Xã Thuợng Nung, huyện Võ Nhai, tỉnh Thái Nguyên tháng 12/2019)

Để có cái nhìn toàn diện, khách quan hơn, tác giả đã tiến hành phỏng vấn sâu (Đối tượng được chọn phỏng vấn sâu gồm: 2 cán bộ xã; 07 trưởng xóm và 80 hộ dân thuộc 7 xóm trên địa bàn xã. Cụ thể: Xóm Lũng Cà và Xóm Lũng Luông, mỗi xóm 15 hộ, các xóm còn lại là 10 hộ/xóm). Kết quả thu được như sau:

Về nhà ở của người dân tại xã Thuợng Nung: Qua quan sát và phỏng vấn sâu 80 hộ dân thì có tới 49 hộ đang sống trong những ngôi nhà tạm bợ sập sệ, không kiêm cố. Nhà ở của người dân được dựng trên những sườn đồi cheo leo, tường nhà chỉ đơn giản là những mảnh gỗ tạp ghép tạm hoặc tấm phên nứa bao quanh. Với một địa phương có khí hậu khắc nghiệt như Võ Nhai (thường xảy ra tình trạng sạt lở đất vào mùa mưa, sương muối vào mùa đông) thì nhà ở của người dân chưa đảm bảo an toàn: Cụ thể: Xóm Lũng Cà: 14/15 hộ dân; Xóm Lũng Luông là 13/15 hộ dân; Xóm: Luỗng Hoài: 6/10 hộ dân; Xóm Tân Thành: 4/10 hộ dân; Xóm Lục Thành: 3/10 hộ dân; Xóm Trung Thành: 5/10 hộ dân; Xóm An Thành: 4/10 hộ dân. Như vậy, tình trạng nghèo đói về nhà ở vẫn tập trung chủ yếu tại hai xóm Lũng Cà và Lũng Luông và cả xóm Luỗng Hoài. Mặc dù, trong thời gian qua, chính quyền xã Thượng Nung cũng đã thực hiện chính sách hỗ trợ kinh phí sửa chữa, xây mới về nhà ở cho các hộ nghèo trên địa bàn xã. Tuy nhiên, do kinh phí hạn hẹp trong khi số hộ nghèo cần hỗ trợ lại đông nên tình trạng nghèo về nhà ở vấn là vấn đề cần phải quan tâm đặc biệt trong thời gian tới.

Về đời sống của ngườ dân: Kết quả phỏng vấn sâu 80 hộ dân trên địa bàn xã, có tới 63/80 hộ dân có đời sống còn gặp nhiều khó khăn, đặc biệt tại hai xóm Lũng Cà, Lũng Luông (24/30 hộ dân của hai xóm được phỏng vấn), cho biết bữa ăn hàng ngày của họ chủ yếu là ngô và rau dại được lấy ở rừng. Trên địa bàn xã, hiện đã có công trình nước sạch phục vụ mục đích dân sinh nhưngvẫn còn rất nhiều hộ dân (70/80 hộ dân được phỏng vấn) trong xã vẫn sử dụng nước tự nhiên cho sinh hoạt, trong đó phần lớn là dùng nguồn nước tự chảy và nước suối. Khi được hỏi, đa phần người dân cho biết "Chúng tôi quen dùng nguồn nước tư nhiên rồi, dùng nuớc sạch chúng tôi không quen”. Như vậy, có thể thấy 
nhận thức của người dân nơi đây về lợi ích của nước sạch trong sinh hoạt hàng ngày còn khá hạn chế. Về nguồn nước sản xuất nông nghiệp nơi đây cũng chủ yếu phụ thuộc vào nước trời.

Về giao thông đi lại: Giao thông đi lại nơi đây đã và đang trở thành một trong những rào cản gây khó khăn không nhỏ đối với đời sống của người dân tại xã, nhất là giao thông đi lại của hai xóm Lũng Cà, Lũng Luông, chủ yếu là đường mòn nhỏ, mùa mưa lầy lội khó khăn cho việc đi lại của bà con nơi đây. Đường sá đi lại khó khăn đã khép bà con cách biệt với sự phát triển của xã hội bên ngoài như trăn trở của Trưởng xóm Lũng Cà và Lũng Luông: “mong muốn có ánh điện, có ti vi để bà con thấy được ở ngoài kia xã họi phát triển nhu thế nào". Rõ ràng, nỗi niềm ấy không thể giải quyết được trong một sớm một chiều.

Việc được sủ dụng điện luới quốc gia của các hộ dân tại xã Thuợng Nung). Việc đưa điện lưới quốc gia về từng hộ dân trên địa bàn xã cũng đã được Ủy ban nhân dân xã quan tâm, tuy nhiên, do các hộ dân cư sống thưa thớt tại các dải núi khác nhau nên việc kéo điện tới các xóm là vô cùng khó khăn, tỉ lệ hộ gia đình không có điện thắp sáng, thiếu các phương tiện nghe nhìn, đời sống của người dân ở đây còn khá cao. Theo như kết quả phỏng vấn sâu thì có tới 45/80 tổng số hộ được phỏng vấn là chưa có điện lưới. Cuộc sống của họ chủ yếu là đèn dầu, số hộ dân có tivi phục vụ đời sống tinh thần cũng chiếm với số lượng khá khiêm tốn là 20/80 hộ dân được hỏi.

\subsection{Nguyên nhân dẫn đến thỵc trạng nghèo đói} tại xã Thưọng Nung, huyện Võ Nhai, tỉnh Thái Nguyên

Qua kết quả phỏng vấn sâu, tác giả nhận thấy có rất nhiều nguyên nhân dẫn đến thực trạng nghèo đói của người dân tại xã Thượng Nung, huyện Võ Nhai, tỉnh Thái Nguyên trong thời gian qua, được thể hiện ở Bảng 4 dưới đây.

Bảng 4: Tỉ lệ nguyên nhân dẫn đến nghèo đói tại xã Thuợng Nung, huyện Võ Nhai, tỉnh Thái Nguyên

\begin{tabular}{|c|c|c|c|c|c|c|c|c|c|c|}
\hline \multicolumn{11}{|c|}{ Nguyên nhân dẫn đến đói nghèo tại xã Thưọng Nung, huyện Võ Nhai, tỉnh Thái Nguyên } \\
\hline & $\begin{array}{c}\text { Thiếu } \\
\text { vốn sản } \\
\text { xuất }\end{array}$ & $\begin{array}{c}\text { Thiếu } \\
\text { đất } \\
\text { canh } \\
\text { tác }\end{array}$ & $\begin{array}{c}\text { Thiếu } \\
\text { phương } \\
\text { tiện sán } \\
\text { xuất }\end{array}$ & $\begin{array}{c}\text { Thiếu } \\
\text { lao } \\
\text { động }\end{array}$ & $\begin{array}{c}\text { Cólao } \\
\text { động } \\
\text { nhưng } \\
\text { không có } \\
\text { việc làm }\end{array}$ & $\begin{array}{c}\text { Không biết } \\
\text { cách làm ăn } \\
\text { không có } \\
\text { tay nghề }\end{array}$ & $\begin{array}{l}\text { Đông } \\
\text { người } \\
\text { ăn theo }\end{array}$ & $\begin{array}{c}\text { Ốm } \\
\text { đau } \\
\text { nặng }\end{array}$ & $\begin{array}{c}\text { Mắc tệ } \\
\text { nạn xã } \\
\text { hội }\end{array}$ & $\begin{array}{c}\text { Chây } \\
\text { lười lao } \\
\text { động }\end{array}$ \\
\hline $\begin{array}{l}\text { Tỉ lệ } \\
(\%)\end{array}$ & 13,7 & 25,6 & 19,7 & 2,6 & 8,5 & 6,8 & 13,7 & 0,9 & 2,6 & 27,3 \\
\hline
\end{tabular}

(Nguồn: Kết quả phỏng vấn sâu)

Qua Bảng 4, có thể thấy các nguyên nhân cơ bản dẫn đến thực trạng nghèo đói tại xã Thượng Nung, huyện Võ Nhai, tỉnh Thái Nguyên đó là:

\section{* Nhóm các nguyên nhân khách quan}

Thứ nhất, nghèo đói do điều kiện tự nhiên không thuận lợi, dẫn đến thiếu đất canh tác chiếm tỉ lệ 25,6\%. Thực tế cho cho thấy, xã Thượng Nung, huyện Võ Nhai nằm tại phía bắc của huyện Võ Nhai và có sông Nghinh Tường cùng các con suối phụ lưu chảy trên địa bàn. Địa hình của xã khá phức tạp, chủ yếu là đồi núi. Nơi đây có khối núi đá vôi đồ sộ nhất tỉnh Thái Nguyên, rộng tới $300 \mathrm{~km}^{2}$, độ cao từ 500 đến 600 mét, kéo dài từ Thần $\mathrm{Sa}$ qua Nghinh Tường, đến Liêm Thuỷ (huyện $\mathrm{Na}$ Rì, tỉnh Bắc Cạn). Những đặc điểm này gây khó khăn không nhỏ cho hoạt động sản xuất của bà con nhân dân sinh sống trên địa bàn xã mà còn làm cho tình trạng thiếu đất canh tác càng trở nên trầm trọng hơn.

Thư hai, nghèo đói do thiếu phưong tiện sản xuất với tỉ lệ 19,7\%. Thiếu phương tiện sản xuất cũng là một trong những nguyên nhân cơ bản dẫn đến nghèo đói của người dân xã Thượng Nung. Kết quả phỏng vấn có tới $100 \%$ số hộ được hỏi đều thiếu phương tiện sản xuất nên phải đi thuê hoặc mượn lại của người khác trong vùng.

Thứ ba, nghèo đói do thiếu vốn sản xuất, chiếm $13,7 \%$. Vốn cũng là vấn đề được người dân quan tâm khi muốn nâng cao năng suất trồng trọt và chăn nuôi cũng như mở rộng sản xuất, nhưng đại bộ phận người dân không có vốn nên việc đầu tư cho chăn nuôi, trồng trọt gặp rất nhiều khó khăn. Cùng với đó, người dân chủ yếu sử dụng công cụ sản xuất còn thô sơ, lạc hậu trong quá trình canh tác nên năng suất không cao, khiến đời sống của người xã Thượng Nung đã khó khăn lại càng khó khăn hơn.

\section{* Nhóm các nguyên nhân chủ quan}

Thư nhất, nghèo đói do chây luời lao động chiếm $27,3 \%$. Có thể thấy đây là nguyên nhân cơ bản nhất, 
chiếm tỉ lệ cao nhất dẫn đến thực trạng đói nghèo của người dân nơi đây. Tâm lý chông chờ, ỉ lại cộng với tư tưởng muốn thụ hưởng chính sách giảm nghèo trong thời gian dài cũng như việc nhận thức không đầy đủ trách nhiệm của bản thân trong việc tự lực lao động để vươn lên thoát nghèo của một đại bộ phận dân cư tại xã Thượng Nung chính là nguyên nhân dẫn đến hiện trạng đói nghèo của xã Thượng Nung trong thời gian qua còn chiếm tỉ lệ cao.

Thư hai, nghèo đói do đông nguời ăn theo, chiếm $13,7 \%$. Theo như kết quả điều tra được cho thấy, mỗi gia đình tại xã Thượng Nung thường có từ 5 đến 6 khẩu/hộ, trong khi lao động chính tạo ra thu nhập nuôi sống cả gia đình cũng chỉ có từ 1 đến 2 người. Do vậy, rất nhiều hộ gia rơi vào tình cảnh không đảm bảo được cuộc sống tối thiểu của gia đình.

Thư ba, có lao động nhung không có việc làm, chiếm $8,5 \%$. Về cơ bản mà nói người dân tại xã Thượng Nung chỉ quen với công việc của nhà nông như trồng trọt, chăn nuôi, tuy nhiên, do điều kiện tự nhiên không ưu ái, không có đất canh tác, không có phương tiện sản xuất nên nhiều gia đình có lao động nhưng lại không có việc làm.

Thứ tur, nghèo đói do không biết cách làm ăn không có tay nghề, chiếm 6,8\%. Đa số dân cư của xã Thượng Nung là người dân tộc thiểu số, trình độ dân trí thấp nên khả năng tiếp cận với công nghệ cũng như những công việc đòi hỏi trình độ chuyên môn thì không thể đáp ứng nên mặc dù có lao động nhưng rất nhiều hộ vẫn đói nghèo là vì không tìm được việc phù hợp để làm.

Ngoài ra, còn một số nguyên nhân khác nữa như: Ốm đau nặng (0,9\%); Mắc tệ nạn xã hội (2,6\%) và thiếu lao động (2,6\%), các nguyên nhân này chiếm tỉ lệ nhỏ, nhưng cũng những nguyên nhân góp phần đưa đến sự nghèo đói của người dân xã Thượng Nung trong thời gian qua.

\subsection{Thực hiện chính sách xóa đói giảm nghèo tại} xã Thuọng Nung giai đoạn 2016-2019

Từ năm 2016 đến nay, UBND xã Thượng Nung đã triển khai đồng bộ các dự án, chính sách xóa đói giảm nghèo đến cơ sở xóm và từng đối tượng hưởng thụ, đồng thời chủ động phân công, bố trí lực lượng tổ chức thực hiện chương trình ở cơ sở. Kết quả thực hiện từng chính sách giảm nghèo trên địa bàn giai đoạn 2016-2019 được thể hiện cụ thể như sau.

* Chính sách hỗ trợ dạy nghề và việc làm

Công tác dạy nghề cho người nghèo, gắn với giải quyết việc làm là một trong những giải pháp giải quyết một số khó khăn cho người nghèo như thu nhập thấp, thiếu đất sản xuất, chuyển đổi ngành nghề phù hợp. Năm 2019, Hội phụ nữ xã mới mở được lớp đào tạo nghề may công nghiệp thu hút 40 lao động tại địa phương tham gia. Đây là con số còn khiêm tốn so với thực trạng người dân không có việc làm ở xã.

* Chính sách hỗ trợ về y tế

Giai đoạn 2016-2019, xã đã thực hiện cấp phát 8.531 lượt thẻ BHYT cho người dân tộc thiểu số ở vùng đặc biệt khó khăn và 113 lượt thẻ cho người Kinh sinh sống ở vùng đặc biệt khó khăn. Công tác lập danh sách và cấp phát thẻ BHYT của một số đối tượng đã được triển khai thực hiện và kịp thời phục vụ công tác khám chữa bệnh của đối tượng hưởng thụ. Công tác khám chữa bệnh và chăm sóc sức khỏe cho người dân đã được xã thực hiện tương đối tốt, chất lượng khám chữa bệnh cho các đối tượng từng bước được nâng lên. Đặc biệt công tác khám chữa bệnh bảo hiểm y tế hàng năm đều có đạt trên 2000 lượt người chiếm trên $85 \%$ tổng số lượt khám chữa bệnh tại Trạm y tế xã.

* Chính sách hỗ trọ về giáo dục và đào tạo

Mạng lưới trường lớp, cơ sở vật chất phục vụ giáo dục các cấp học được xã quan tâm đầu tư; thực hiện kịp thời, đúng đối tượng các chính sách về miễn, giảm học phí cho học sinh là con em đồng bào dân tộc thiểu số, hộ nghèo, học sinh sinh sống ở xã đặc biệt khó khăn. Qua đó đã tạo cho học sinh con hộ nghèo có điều kiện học tập tốt hơn, giảm bớt khó khăn cho gia đình và các em học sinh, từ đó nâng cao tỷ lệ đi học chuyên cần ở các xóm vùng cao, góp phần nâng cao chất lượng giáo dục toàn diện của xã. Tổng số lượt học sinh được nhận hỗ trợ: $3.861 \mathrm{em}$. Tổng số tiền hỗ trợ 2.293,29 triệu đồng. Trong đó số học sinh, trẻ mẫu giáo thuộc hộ nghèo được miễn giảm học phí là 1.789 em; số học sinh, trẻ mẫu giáo thuộc hộ nghèo được hỗ trợ chi phí, đồ dùng học tập là $1.972 \mathrm{em}$; số trẻ em được hỗ trợ ăn trưa tại trường theo Nghị định số 116/2016/NĐ-CP là 114 em.

* Chính sách hỗ trọ về nhà ở cho nguời nghèo

Xã đã tích cực triển khai chính sách hỗ trợ hộ nghèo nhu cầu vay vốn làm nhà ở theo Quyết định số 33/2015/QĐ-TTg của Thủ tướng chính phủ đến từng cơ sở xóm. Tổng số hộ có nhu cầu vay vốn là 15 hộ, tổng số vốn vay là 370 triệu đồng giúp cho hộ nghèo xóa được nhà tạm, ổn định cuộc sống.

* Chính sách hỗ trợ vay vốn uu đãi

Giai đoạn 2016-2019, xã đã tiến hành cho vay hộ nghèo đạt 234 hộ với tổng số vốn 5.167 triệu đồng, 
133 hộ cận nghèo với số vốn chiếm 3.174 triệu đồng, 17 hộ thoát nghèo với số vốn 665 triệu đồng, hộ được vay vốn theo Quyết định 2085 là 05 hộ với 200 triệu đồng. Tỷ lệ lượt hộ nghèo, hộ cận nghèo được vay vốn ưu đãi chiếm 110,7 \% tổng số hộ nghèo và hộ cận nghèo trên địa bàn xã. Công tác cho vay uỷ thác cho 4 hội, đoàn thể là: Nông dân, Phụ nữ, Cựu chiến binh và Đoàn thanh niên được Ngân hàng chính sách xã hội huyện và 4 tổ chức Hội, Đoàn thể tổ chức đánh giá thực hiện trong những năm qua, củng cố và tăng cường trách nhiệm nhằm thực hiện tốt các chương trình tín dụng nhà nước. Nhờ chính sách tín dụng ưu đãi mà trong những năm qua, đa số người nghèo đều có vốn để đầu tư cho sản xuất kinh doanh, người nghèo mạnh dạn hơn trong việc vay vốn, ý thức trách nhiệm cũng như kinh nghiệm sử dụng vốn vay được nâng lên. Đây chính là yếu tố quan trọng mang lại kết quả xoá đói giảm nghèo nhanh, bền vững trong nhân dân.

\section{* Chính sách trọ giúp pháp lý}

Chính sách trợ giúp pháp lý đã góp phần đảm bảo đáp ứng kịp thời nhu cầu trợ giúp pháp lý của người nghèo và đồng bào dân tộc thiểu số địa phương, góp phần tích cực trong việc nâng cao nhận thức pháp luật cho nhân dân. Giai đoạn 2016-2019 xã đã phối hợp cùng Trung tâm trợ giúp pháp lý của tỉnh và của huyện tổ chức được 05 đợt phổ biến pháp luật và trợ giúp pháp lý lưu động tới địa bàn các xóm trong xã đến 450 lượt người trong đó có 382 lượt người là người nghèo.

\section{* Chính sách hỗ trợ về nước sinh hoạt}

Theo như kết quả thống kê, giai đoạn 2016 2019, xã đã thực hiện hỗ trợ về nước sinh hoạt cho 44 hộ nghèo theo Quyết định số 755/QĐ-TTG năm 2014 của Thủ tướng chính phủ với tổng số tiền hỗ trợ 87.2 triệu đồng góp phần nâng cao chất lượng sinh hoạt của người nghèo.

\section{* Chính sách hỗ trọ tiền điện}

Đã thực hiện hỗ trợ cho 100\% hộ nghèo với đồng số tiền 553,635 triệu đồng. Chính sách hỗ trợ tiền điện đã hỗ trợ một phần đời sống sinh hoạt của hộ nghèo, tác động tích cực đến sản xuất kinh doanh của một số hộ gia đình nghèo. Việc ban hành các văn bản hướng dẫn về hướng dẫn chi trả tiền điện cho hộ nghèo và phân bổ kinh phí kịp thời đã giúp cho việc triển khai thực hiện tại cơ sở được đúng thời gian.

Tóm lại: Nhờ thực hiện tốt các chính sách xóa đói giảm nghèo trong giai đoạn 2016-2019 mà xã Thượng Nung đã đạt được những kết quả nhất định trong công tác giảm nghèo tại địa phương. Cụ thể: Xã đã giảm tỷ lệ hộ nghèo từ $54.33 \%$ đầu năm 2016 xuống còn $38.66 \%$ cuối năm 2019; 100\% người dân tộc thiểu số, người kinh sinh sống ở vùng ĐBKK được cấp thẻ BHYT miễn phí; 100\% học sinh thuộc hộ nghèo, hộ cận nghèo và học sinh thuộc vùng 135 được hưởng các chế độ miễn giảm, hỗ trợ chi phí học tập; 100\% hộ nghèo có nhu cầu về vốn được vay vốn ưu đãi để sản xuất kinh doanh. Tuy nhiên, trong quá trình thực hiện các chính sách xóa đói giảm nghèo, tỉ lệ hộ nghèo của xã vẫn chiếm tỉ lệ cao với 35,5\%. Do vậy, làm thế nào để giảm nghèo trong thời gian tới vẫn là bài toán của xã Thượng Nung trong thời gian tới.

Tuy nhiên, trong quá trình thực hiện các chính sách xóa đói giảm nghèo tại xã Thượng Nung vẫn còn tồn tại một số hạn chế như sau:

* Đối với việc thực hiện chính sách hố trọ dạy nghề và việc làm:

Tỷ lệ lao động qua đào tạo còn thấp; số lượng lao động có việc làm tăng thêm hàng năm không cao nên việc giải quyết việc làm cho người dân vẫn còn là một thách thức lớn đối với xã Thượng Nung trong thời gian tới. Kết quả phỏng vấn sâu cho thấy: chính sách hỗ trợ dạy nghề và việc làm chưa được địa phương và người dân chú trọng triển khai thực hiện. Nguyên nhân là do việc khảo sát nhu cầu học nghề tại địa phương chưa được quan tâm, mức hỗ trợ tiền ăn cho người học nghề thấp, do vậy chưa khuyến khích được nhiều người học.

* Đối với việc thực hiện chính sách hỗ trọ về y tế: Việc cung cấp dịch vụ y tế ở tuyến cơ sở còn hạn chế, chất lượng nguồn nhân lực chưa đáp ứng được nhu cầu khám chữa bệnh cho đối tượng. Nhận thức của người nghèo về chăm sóc sức khỏe cho chính mình chưa thực sự được quan tâm, nguyên nhân cũng là do công tác tuyên truyền về chăm sóc sức của chính quyền xã tới bà con nơi đây chưa được thực hiện tốt.

* Đối với việc thực hiện các chính sách hố trợ về nhà ở cho người nghèo: Mức hỗ trợ và cho vay xây dựng nhà quá thấp so với kinh phí để xây dựng nhà ở chưa thật sự phù hợp với tình hình thực tế, trong khi hộ nghèo không có khả năng đối ứng (mức hỗ trợ và cho vay chỉ đáp ứng được khoảng 30 - 40\% kinh phí để xây dựng nhà ở cho hộ nghèo). Hiện nay, ngoài việc cho vay xây dựng nhà thì việc huy động các nguồn vốn khác để thực hiện chính sách hỗ trợ nhà ở trên địa bàn xã còn gặp nhiều khó khăn do yêu cầu hộ nghèo, hộ cận nghèo có nhu cầu hỗ trợ về nhà ở cần phải có giấy chứng nhận quyền sử dụng đất ở. Nhưng trên thực tế một số địa bàn như 3 xóm Lũng 
Hoài, Lũng Cà, Lũng Luông có tỷ lệ hộ nghèo, hộ cận nghèo cao chủ yếu người dân sinh sống trong vùng quy hoạch đất rừng phòng hộ nên không thể chuyển đổi mục đích sử dụng đất và cấp giấy chứng nhận quyền sử dụng đất cho người dân.

* Đối với việc thục hiện các chính sách hỗ trọ vay vốn uu đãi: Trong thực hiện chính sách tín dụng ưu đãi vẫn còn một số tồn tại như: Vẫn còn một bộ phận người nghèo do nhiều nguyên nhân mà chưa tiếp cận với nguồn; một số sử dụng nguồn vốn được vay chưa hiệu quả; chưa lồng ghép tốt việc cho vay với việc hướng dẫn sử dụng vốn cho nên còn một bộ phận người nghèo vay vốn nhưng chưa thoát nghèo được.

* Đối với việc thực hiện các chính sách trợ giúp pháp lý: Đa số các hộ nghèo chưa chủ động tìm hiểu, trang bị các kiến thức về pháp luật mà chỉ có nhu cầu hỗ trợ khi gặp các vướng mắc liên quan đến pháp luật.

\section{4. Đề xuất một số giải pháp góp phần giảm} nghèo trên địa bàn xã Thượng Nung, huyện Võ Nhai, tỉnh Thái Nguyên

Trên cơ sở phân tích thực trạng nghèo đói và nguyên nhân dẫn đến nghèo đói tại xã Thượng Nung, huyện Võ Nhai, tác giả xin đề xuất một số giải pháp sau:

Thứ nhất: Tổ chức khảo sát đưa ra các mô hình trồng cây ăn quả, vật nuôi phù hợp với khí hậu, địa hình và đất đai của xã. Với địa hình đa phần là đồi núi đá vôi, nơi đây cũng thuận lợi cho việc trồng cây công nghiệp ngắn ngày và chăn thả gia súc, đàn trâu, đàn bò phát triển khá tốt, song nếu chỉ dựa vào các cây trồng, vật nuôi hiện tại thì không thể giảm nghèo nhanh và bền vững. Vì vậy, xã nên khảo sát điều kiện khí hậu, thổ nhưỡng để tìm ra các trồng cây ăn quả có hiệu quả kinh tế cao phù hợp địa hình, khí hậu, thổ nhưỡng tại địa phương. Chẳng hạn: Có thể nghiên cứu mô hình trồng quýt của một số xã như Chiến Thắng, Nhất Hòa, Vũ Sơn,... tại huyện Bắc Sơn, tỉnh Lạng Sơn, bởi địa hình của những xã này giống với xã Thượng Nung là núi đá vôi bao phủ nhưng đã trở thành một vùng chuyên canh quýt nổi tiếng đem đến thu nhập từ 50 triệu đến 100 triệu đồng/năm cho người dân của xã. Đồng thời, xã cũng cần có cơ chế hỗ trợ thỏa đáng để bà con phát triển các mô hình này. Bên cạnh đó, xã cũng cần nghiên cứu thêm các giống vật nuôi phù hợp địa hình, khí hậu tại địa phương để triển khai tới bà con nơi đây. Có thể chăn nuôi trâu bò không còn là thế mạnh, trong khi giá thịt bò, thịt lợn có mức biến động rất lớn và thường không ổn định thì ngược lại, giá thịt dê gần như không có biến động gì nhiều. Bên cạnh đó, nhiều dự báo cho rằng nhu cầu về thịt dê sẽ tăng trong tương lai nên có thể nghiên cứu chuyển đổi từ nuôi trâu bò sang nuôi dê trên núi đá.

Chính quyền xã cần quan tâm hơn nữa đến việc khảo sát nhu cầu học nghề của người dân tại địa phương. Để từ đó, xây dựng kế hoạch, chương trình đào nghề sát với nhu cầu, mong muốn người dân. Bên cạnh đó, cũng cần có kinh phí hỗ trợ tiền ăn hợp lý cho người học nghề để khuyến khích được nhiều người đi học.

Thư hai, hố trợ về chuyển đổi co cấu cây trồng, vật nuôi cho ngươi dân noi đây. Như đã đề cập ở trên thiếu phương tiện sản suất mà ở đây là thiếu đất canh tác đang là nguyên nhân quan trọng thứ hai khiến nhiều người dân nơi đây rơi vào tình cảnh nghèo đói. Do vậy, đối với nhưng hộ gia đình có đất canh tác (Trồng lúa, trồng ngô,...) giờ không còn phù hợp thì chính quyền xã cũng cần có tư vấn chuyển sang trồng cỏ, hay chồng cây ăn quả đem lại lợi ích cao hơn. Bên cạnh đó, có hỗ trợ cho người dân đầu vào để người dân thực hiện.

Thư ba: hố trọ nhũng thông tin về việc làm cho người dân trên địa bàn xã. Giải quyết vấn đề việc làm cho người dân trên địa bàn xã cũng là mấu chốt quan trọng để thoát nghèo. Khi được hỏi về nhu cầu tìm việc làm để có thu nhập tốt hơn thì có tới hơn $80 \%$ thanh niên trả lời rất mong muốn có được một công việc ổn định để cải thiện cuộc sống gia đình. Xuất phát từ nguyện vọng của người dân, trong thời gian tới xã nên chủ động, năng động trong việc tìm kiến những thông tin việc làm từ Trung tâm giới thiệu việc làm trên đại bàn huyện Võ Nhai, tỉnh Thái Nguyên cũng như các doanh nghiệp cần tuyển dụng lao động để kịp làm cầu nối cho những thanh niên có nhu cầu tìm việc với các nhà tuyển dụng. Trước mắt, xã có thể tìm kiếm thông tin việc làm trực tiếp ở một số công ty lớn có nhu cầu tuyển dụng với số lượng lao động đông, nhưng lại không đòi hỏi trình độ cao ở người lao động, mức lương tương đối cao đang đóng trên địa bàn tỉnh Thái Nguyên như: Tập đoàn Sam Sung ở Phổ Yên; Công ty thương mại và Cổ phần May TNG Thái Nguyên; Công ty GLonis ở phường Phú Xá, thành phố Thái Nguyên; Công ty May TDT ở Phú Bình Thái Nguyên, v.v....

Thư tu, tăng cương tổ chúc hướng dẫn việc triển khai kỹ thuật vào sản xuất cho nguời dân trên địa bàn xã nhằm tạo điều kiện để ho tiếp cận đuợc với 
nhũng tiến bộ khoa học - kỹ thuật trong sản xuất. Bên cạnh việc mở rộng hỗ trợ bà con về vốn phát triển kinh tế, giống, và các điều kiện sản xuất khác thì điều quan trọng là tổ chức, hướng dẫn bà con khoa học kỹ thuật nuôi trồng tiên tiến để bà con áp dụng, thay thế cho cách canh tác lạc hậu vốn mang lại năng suất và hiệu quả kinh tế thấp. Tăng cường phổ biến, giới thiệu các mô hình phát triển kinh tế giảm nghèo bền vững cho người dân, để họ học tập, áp dụng giảm nghèo cho mình. Hiện nay đa số dân cư tại xã Thượng Nung, huyện Võ Nhai lại áp dụng những phương thức canh tác còn lạc hậu, chưa có áp dụng những tiến bộ khoa học - kỹ thuật vào sản xuất nên năng suất rất thấp. Do đó, cùng với việc hỗ trợ cho dân cư về con giống, cây giống để phát triển mô hình trồng cây ăn quả là cây quýt và mô hình chăn nuôi dê trên núi đá vôi thì xã cần cử cán bộ khuyến nông đến từng hộ để hướng dẫn trực tiếp về cách trồng, cách chăm sóc con giống, cây giống, làm tốt công tác hỗ trợ về kỹ thuật canh tác sẽ góp phần không nhỏ vào việc nâng cao năng suất sản xuất cho người dân, từ đó giúp nâng cao được đời sống của người dân.

Thư năm, đẩy mạn công tác tuyên truyền nhằm nâng cao nhận thức cho nguò̀i nghèo hiểu được trách nhiệm vuoon lên thoát nghèo, không ỷ lại, trông chờ vào sự hỗ trợ của Nhà nước.

Theo kết quả điều tra cho thấy nguyên nhân nghèo do chây lười lao động tại xã Thượng Nung chiếm đến 27,3\%, đây là con số không hề nhỏ. Mọi sự cố gắng của nhà nước hay chính quyền địa phương sẽ trở nên vô nghĩa nếu như bản thân mỗi người dân không ý thức được trách nhiệm vươn lên thoát nghèo của mình. Do vậy, việc tăng cường công tác tuyên truyền cho người dân hiểu được trách nhiệm của mình trong công cuộc xóa đói giảm nghèo là việc làm vô cùng cần thiết, có ý nghĩa quyết định đến sự thành công của công tác xóa đói giảm nghèo trong cả nước nói chung và tại xã Thượng Nung, huyện Võ Nhai, tỉnh Thái Nguyên nói riêng. Để làm tốt được việc này, tác giả cho rằng chính quyền xã cần phối, kết hợp chặt chẽ với các ban ngành, Mặt trận Tổ quốc và các đoàn thể, tổ chức chính trị, xã hội như Hội phụ nữ, Hội cựu chiến binh; Hội nông dân, Đoàn thanh niên của xã cũng như các xóm thuộc xã trong việc quán triệt sâu sắc chủ trương, chính sách của Đảng, Nhà nước đến từng cán bộ, đảng viên, người dân...

Trong quá trình thực hiện cần lồng ghép với các chương trình và vận động, khuyến khích đảng viên, đoàn viên, hội viên vươn lên làm giàu chính đáng. Đối với những đảng viên, đoàn viên, hội viên thuộc diện đói nghèo, nghèo, cần phải tuyên truyền giáo dục cho họ thấy rằng đói, nghèo là sự tổn thương, bất hạnh phải sớm thoát khỏi bằng sự tự lực, tự cường vươn lên của bản thân và gia đình họ là chính... Cùng với đó, cần có hình thức khen thưởng đối với những hộ gia đình vươn lên thoát nghèo và biểu dương các hộ gia đình không tái nghèo trở lại. Giao trách nhiệm này cho các trưởng xóm phụ trách và cần có báo cáo cụ thể về công tác tuyên truyền xóa đói giảm nghèo tới người dân hàng tháng cho xã.

Thư sáu: Kết hợp công tác tuyên truyền với áp dụng các huơng uớc của xóm trong việc thực hiện công tác dân số kế hoạch hóa gia đình để giảm bớt tỉ lệ sinh con của ngườ dân đây. Như đã biết, đông con là một trong những nguyên dân cơ bản dẫn đến nghèo đói của người dân tại xã Thượng Nung. Để đẩy được cái đói, cái nghèo trong thời gian tới, bên cạnh làm tốt công tác tuyên truyền về công tác dân số kế hoạch hóa gia đình để người dân nhận thức được thì chính quyền xã cần cũng kết hợp với các trưởng xóm thực hiện cả các hương ước của xóm trong quá trình thực hiện. Trong trường hợp, người dân cố tình, hoặc thực hiện không đúng, chính quyền xã cũng cần có các biện pháp mạnh hơn như có thể phạt hành chính các gia đình sinh quá số con quy định,..

Kết luận: Trong những năm qua, xã Thượng Nung, huyện Võ Nhai, tỉnh Thái Nguyên đã đạt được những kết quả nhất định trong công tác xóa đói giảm nghèo như tỉ lệ hộ nghèo giảm từ $54,33 \%$ xuống còn $38,66 \%$, tuy nhiên đây vẫn là một tỉ lệ khá cao. Thông qua việc phân tích các nguyên nhân dẫn đến nghèo đói tại xã, tác giả đã mạnh dạn đề xuất một số giải pháp góp phần nâng cao hiệu quả công tác xóa đói giảm nghèo của xã Thượng Nung, huyện Võ Nhai, tỉnh Thái Nguyên trong thời gian tới như sau: (1) Tổ chức khảo sát đưa ra các mô hình trồng cây ăn quả, vật nuôi phù hợp với khí hậu, địa hình và đất đai của xã; (2) Hỗ trợ về chuyển đổi cơ cấu cây trồng, vật nuôi cho người dân nơi đây; (3) Hỗ trợ những thông tin về việc làm cho người dân trên địa bàn xã; (4) Tăng cường tổ chức hướng dẫn việc triển khai kỹ thuật vào sản xuất cho người dân trên địa bàn xã nhằm tạo điều kiện để họ tiếp cận được với những tiến bộ khoa học - kỹ thuật trong sản xuất; (5) Đẩy mạnh công tác tuyên truyền nhằm nâng cao nhận thức cho người nghèo hiểu được trách nhiệm vươn lên thoát nghèo, không ỷ lại, trông chờ vào sự hỗ trợ của Nhà nước; (6) Kết hợp công tác tuyên truyền với áp dụng các hương ước của xóm trong việc thực hiện công tác dân số kế hoạch hóa gia đình để giảm bớt tỉ lệ 
sinh con của người dân đây. Tác giả hy vọng, với những giải pháp được đề xuất này sẽ góp phần giảm tỉ lệ hộ nghèo và cận nghèo tại xã Thượng Nung nói riêng và tại huyện Võ Nhai của tỉnh Thái Nguyên nói chung.

\section{REFERENCES}

[1]. Report on results of socio-economic development of Thuong Nung commune in 2016, 2017, 2018, 2019.

[2]. Report on the statistics of poor and near-poor households of Thuong Nung commune in 2016, 2017, 2018, and 2019.

[3]. Report on the results of the implementation of poverty reduction policies in Thuong Nung commune 2016, 2017, 2018, 2019
[4]. Bui Thi Binh (2010), Some policies need to pay attention to ethnic and mountainous regions when participating in making socio-economic policy decisions. Ha Noi.

[5]. Nguyen Hai Huu: About possible solutions to implement strategic missions of poverty reduction 2001 - 2003. Journal of Science No. 4,2001.

[6]. Nguyen Lan Phuong (2019), Trends affecting poverty reduction in Viet Nam today, Financial Magazine $2^{\text {nd }}$ period in August, 2019.

[7]. Nguyen Lan Phuong (2019), Some sustainable poverty alleviation solutions for central provinces, Financial Magazine $1^{\text {st }}$ period in July, 2019.

\section{THE SITUATION OF POVERTY IN THUONG NUNG COMMUNE, VO NHAI DISTRICT, THAI NGUYEN PROVINCE}

\section{Article info}

Recieved:

27/7/2020

Accepted:

20/9/2020

Keywords:

Poverty, hunger

eradication, poverty

reduction, poverty

reduction, poverty

reduction policies.

\begin{abstract}
The article focuses on clarifying the situation of poverty as well as analyzing the causes leading to poverty and the implementation of poverty reduction policies in Thuong Nung commune, Vo Nhai district, Thai Nguyen province in the period 2016-2019. Since then, proposing a number of solutions to contribute to poverty reduction in the commune in the coming time.
\end{abstract}

